\title{
PENGEMBANGAN USAHA DAN PELESTARIAN ITIK TALANG BENIH
}

\section{BUSINESS DEVELOPMENT AND TALANG BENIH DUCK CONSERVATION}

\author{
Oleh: \\ Wismalinda Rita, Sunaryadi, dan E. Oktavidiati \\ Program Studi Peternakan Fakultas Pertanian Universitas Muhammadiyah Bengkulu \\ vinnagita@gmail.com
}

\begin{abstract}
There is no simple or efficient technology to make local material-based feed such as Durio zibethinus Murr seed powder and mineral proteinates. Partners' low comprehension in nutrition necessity of Talang Benih duck was in line with breeding purpose. Science and Technology Program for society is expected to provide understanding to both partners about hatching management, breeding management and ration composition containing durian seed powder and organic mineral. It is expected that by the end of program, selected Talang Benih ducks were obtained and feed containing durian seed powder was produced. Durian seeds are prevalent waste in Bengkulu province which has not been optimized as duck feed because of the partners' limited knowledge. Durian seeds processing into durian seed powder undergoes steaming process for added-value of durian powder seed which is eventually used as feed for Talang Benih duck in place of yellow cornmeal. Utilization of durian seed powder in duck ration would cut down feed cost thereby increasing farmers' income. Science and Technology Program (IbM) was running well observed from the high interest and zest of partner groups in extension and training programs as they asked questions during the extension and training. Talang Benih duck produced were utilizing feed made of durian seed powder. Both partners involved in this program understood and comprehended hatching management, Talang Benih Duck breeding management, durian seed powder making and management of ration composition utilizing durian seed powder.
\end{abstract}

Keywords: Talang Benih duck, business development, conservation, durian seed powder

\section{PENDAHULUAN}

Itik talang benih merupakan plasma nutfah asli Bengkulu yang ditetapkan berdasarkan keputusan Menteri Pertanian Republik Indonesia Nomor : 2836/kpts/LB.430/2005 tentang rumpun itik talang benih yang diyakini berasal dari Kabupaten Rejang Lebong. Itik ini termasuk sumber hayati ternak yang perlu dilestarikan karena mempunyai keunggulan komparatif antara lain tahan terhadap penyakit, mempunyai daya adaptasi yang cukup baik terhadap lingkungan, bobot dewasa betina bisa mencapai 1,2-1,5 kg, mampu memanfaatkan pakan kualitas rendah dengan produksi yang tetap tinggi dan produknya yang sangat disukai oleh konsumen. Itik ini merupakan salah 
satu jenis unggas yang potensial sebagai penghasil telur. Produktifitas itik ini dapat ditingkatkan melalui pemilihan kualitas bibit yang baik penyediaan pakan yang cukup kualitas dan kuantitas serta memberikan pakan tambahan.

Kendala yang dihadapi oleh kelompok mitra adalah tingginya harga pakan dan cenderung berfluktuasi dan tidak terjamin kontinuitasnya, belum optimalnya pembibitan sehingga DOD yang tersedia terbatas dan belum terseleksi dengan baik. Kelompok Wanita Tani belum menguasai teknologi penetasan, belum adanya teknologi tepat guna/sederhana dalam pembuatan pakan bersumber bahan lokal seperti pemanfaatan tepung biji durian dan mineral proteinat, serta rendahnya pemahaman tentang pembuatan pakan sesuai kebutuhan nutrisi itik.

Biji durian selama ini belum begitu dimanfaatkan dan dibuang begitu saja sebagai limbah sampah. Biji durian sangat potensial dijadikan bahan pakan sumber karbohidrat pengganti sebagian jagung bagi ternak itik karena kandungan nutrient yang baik khususnya karbohidrat dan protein. Tepung biji durian kukus mengandung 8,61\% protein kasar, 0,25\% lemak kasar, 4,13\% serat kasar, 0,04\% kalsium, 0,02\% pospor dan energi metabolisme $3493 \mathrm{kkal} / \mathrm{kg}$. Tepung biji durian dapat menggantikan jagung kuning giling sampai level 10\% dalam ransum ayam broiler (Rita, dkk, 2013).

Tansil (1990) menyatakan bahwa biji durian mengandung 25-40 persen dari berat kering dan 98 persen dari karbohidrat tersebut mudah dicerna.

Faktor pembatas dari biji durian adalah terdapatnya anti nutrisi berupa asam sianida (HCN). Asam sianida bagi ternak unggas dapat mempengaruhi alat pencernaan terutama pada ayam broiler yang memiliki cepat tumbuh. Kandungan asam sianida yang terdapat dalam sel tanaman tidak dalam bentuk bebas, tetapi terikat dalam rangkaian sianogenikglikosida yaitu linamerin. Linamerin ini selalu berada bersama-sama dengan dua enzim yang dapat mengurainya menjadi HCN yaitu enzim linamerase dan hidrosimetilliase (Wiradisastra, 1993). Upaya untuk mengurangi kadar HCN adalah dengan menghambat atau mengaktifkan enzim linamerase atau mencegah glikosida terurai menjadi HCN. Hal ini dapat dilakukan dengan pengolahan secara fisika pengukusan agar unsur-unsur zat antinutrisinya dapat tereleminasi (Conn, 1978). Rita, dkk (2013) melaporkan bahwa pengukusan biji durian selama 15 menit dapat menurunkan asam sianida tepung biji durian sampai $71,48 \%$.

Provinsi Bengkulu potensial sebagai penghasil biji durian dengan produksi mencapai 174.882 ton pertahun dan setiap tahunya akan dihasilkan tepung biji durian sebanyak 14.573,5 ton tepung biji durian (BPS, 2013).

Penyuluhan dan Pelatihan Penetasan Telur Itik Talang Benih, Manajemen Pemeliharaan Itik Talang Benih, teknik pembuatan tepung biji durian, Penyusunan Ransum Itik merupakan langkah yang tepat untuk mengatasi kendala yang dihadapi kedua mitra sehingga diakhir kegiatan dapat dihasilkan bibit itik talang benih (DOD) yang terseleksi dan dihasilkannya pakan ternak itik talang benih berbasis tepung biji durian. 


\section{METODE PENGABDIAN}

IbM dilaksanakan selama 8 bulan dari bulan Maret sampai dengan Oktober 2014 di kelompok Wanita Tani Rumpun Annisa dan Wanita Tani Fatimah yang berada di Kelurahan Bentiring Permai Kota Bengkulu. Kegiatan dilakukan dalam bentuk pendidikan, penyuluhan, pelatihan dan demonstrasi, dan pendampingan pada kelompok mitra dengan tahapan sebagai berikut:

1. Koordinasi dengan kelompok mitra

2. Sosialisasi program IbM pada kelompok mitra

Tahap Pelaksanaan

Pelaksanaan program IbM di kelompok mitra dilakukan dengan metode:

1. Penyuluhan; dilakukan dengan metode ceramah, diskusi dan tanya jawab, bertujuan untuk meningkatkan pengetahuan peternak khususnya anggota Kelompok Tani tentang berbagai aspek peternakan itik talang benih.

2. Pelatihan dan demonstrasi cara penggunaan mesin tetas, seleksi telur yang layak untuk dijadikan telur tetas, penanganan telur selama proses penetasan penangan serta seleksi DOD setelah menetas .

3. Pelatihan dan demonstrasi cara pembuatan tepung biji durian.

4. Pelatihan dan demonstrasi teknik penyusunan ransum itik.

Monitoring dan Evaluasi; secara internal dilakukan oleh pihak LPPM -UMB dan secara eksternal dilakukan oleh reviewer Dikti.

Pelaporan; berupa laporan kemajuan (70\%) dan laporan akhir (100\%).

\section{HASIL DAN PEMBAHASAN}

Tahap awal kegiatan Ipteks bagi masyarakat dilakukan dengan koordinasi tim yang terlibat dalam pengabdian untuk memantapkan tugas dan tanggung jawab masing-masing anggota. Setelah itu dilanjutkan dengan koordinasi antara tim pengabdian dan kelompok Wanita Tani Rumpun Annisa dan kelompok Wanita Tani Fatimah dengan tujuan untuk menetapkan dan menyepakati jadwal pelaksanaan kegiatan. Pada kegiatan ini juga dilakukan sosialisa program pada kedua kelompok mitra.

\section{Kegiatan Penyuluhan}

Program pertama kegiatan adalah penyuluhan manajemen pemeliharaan itik talang benih yang diikuti oleh kedua kelompok mitra. Kegiatan ini mampu meningkatkan pengetahuan dan motivasi anggota kelompok mitra yang terlihat pada sesi diskusi dan tanya jawab. Materi penyuluhan antara lain sebagai berikut:

a. Pengenalan itik talang benih sebagai plasma nutfah ternak Provinsi Bengkulu yang harus dilestarikan.

b. Usaha ternak itik talang benih merupakan usaha yang menjanjikan dan banyak diminati masyarakat. 
c. Penyuluhan tentang pentingnya seleksi bibit untuk memperoleh hasil yang diharapkan.

d. Penyuluhan pemilihan bahan pakan berkualitas dan terjamin ketersediaanya di provinsi Bengkulu yang diharapkan dapat meningkatkan produktivitas itik talang benih.

e. Penyuluhan tentang pencegahan dan penanganan penyakit itik.

\section{Pelatihan dan Demonstrasi}

Pelatihan dan demonstrasi manajemen penetasan dilakukan pada kelompok wanita tani Fatimah. Kelompok mitra memperoleh penyuluhan mengenai pemenfaatan mesin tetas untuk meningkatkan populasi itik talang benih. Adapun materi pelatihan meliputi pengoperasian mesin tetas, penyeleksian telur tetas, penanganan telur tetas, peneropongan telur (candling) dan penanganan DOD saat menetas.

Kegiatan sosialisasi dan praktek pembuatan tepung biji durian dilakukan pada kelompok wanita tani rumpun Annisa, pelatihan ini diikuti juga oleh mahasiswa dan alumni program studi peternakan Universitas Muhammadiyah Bengkulu. Pembuatan tepung biji durian diawali dengan tahapan seleksi dan pencucian biji durian sesuai dengan kriteria. Tahapan ini dilakukan untuk memperoleh biji durian yang tua dan berkualitas baik yang ditandai dengan biji bulat agak lonjong, keras tidak busuk dan tidak ceper. Selanjutnya biji durian dikukus selama 15 menit untuk mengurangi asam cianida (HCN) yang terdapat dalam biji durian dan dilanjutkan dengan pengirisan dan penjemuran sampai kering. Irisan biji durian kering ditepungkan dan disimpan dalam kemasan kedap udara untuk selanjutnya digunakan sebagai bahan pembuatan pakan itik talang benih. Kualitas biji durian yang baik adalah berwarna putih kekuningan yang dihasilkan dari biji durian yang kering pada penjemuran satu hari.
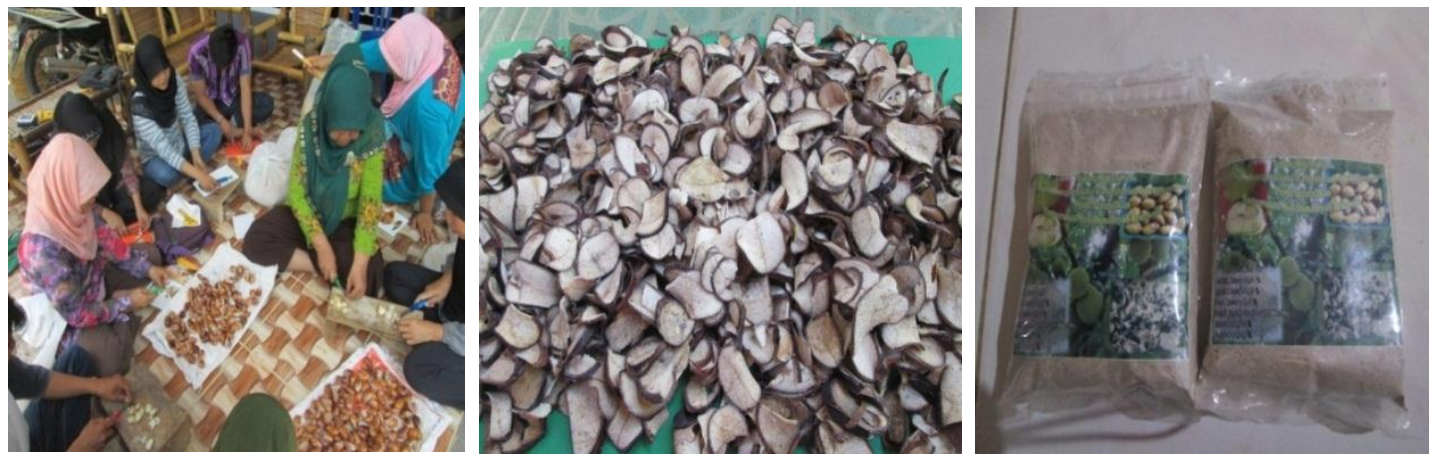

Gambar 1. Pelatihan Pembuatan Tepung Biji Durian

Pelatihan dan demonstrasi pembuatan pakan itik dilakukan setelah tersedia tepung biji durian dan dilanjutkan dengan pengenalan bahan pakan yang akan digunakan yang terdiri dari kosentrat, jagung kuning giling, dedak padi halus dan mineral proteinat. Pelatihan dan demonstrasi meliputi pemilihan kualitas bahan pakan yang baik, zat-zat makanan yang dibutuhkan ternak itik dan kebutuhan nutrisi untuk pakan itik sesuai dengan periode pertumbuhan itik. Pakan diformulasikan dengan menggunakan bahan sebagi berikut yaitu : kosentrat petelur, jagung kuning giling, dedak padi halus dan tepung biji durian. Pada periode stater ransum diformulasikan dengan kandungan protein $18 \%$ dan 
energi metabolisme $2900 \mathrm{kkal} / \mathrm{kg}$ sementara untuk periode grower dan layer diformulasikan ransum dengan kandungan protein 15-17\% dan energi metabolisme 2700 $\mathrm{kkal} / \mathrm{kg}$.

\section{Bimbingan dan Pendampingan}

Kegiatan bimbingan dan pendampingan dilakukan pada saat penetasan oleh kelompok wanita tani Fatimah. Berdasarkan pengamatan di lapangan menunjukkan bahwa pelaksanaan penetasan sudah berjalan dengan baik terlihat dari persentase telur yang berhasil menetas mencapai $65 \%$ pada penetasan tahap dua dibandingkan dengan tahap satu yang mencapai $60 \%$. Telur yang gagal menetas lebih disebabkan oleh beberapa hal antara lain telur infertil (tidak dibuahi), gagal menetas saat piping dan terjadi kematian embrio.
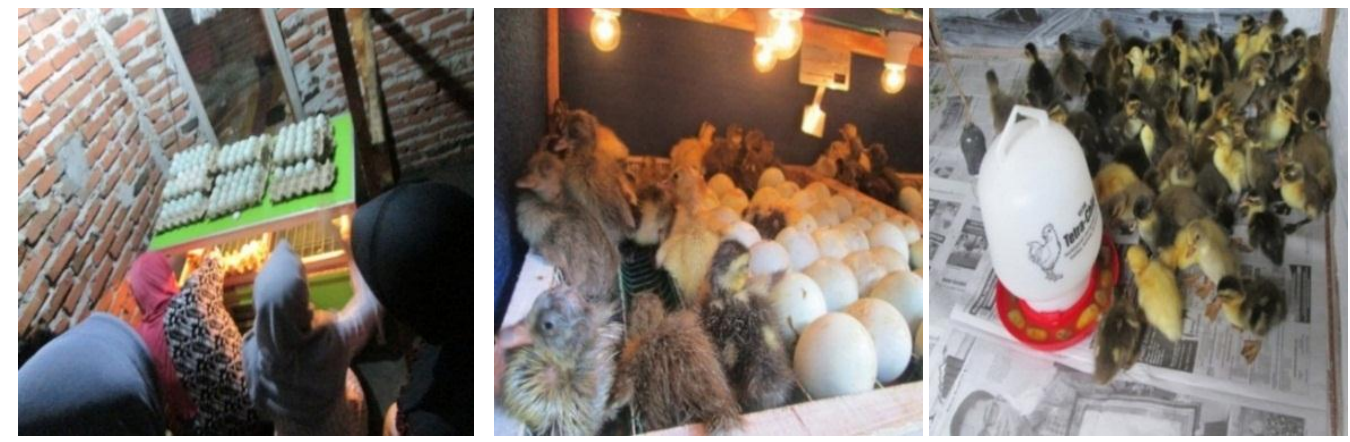

Gambar 2. Pelatihan Manajemen Penetasan

Pada periode stater DOD ditempatkan pada boks DOD yang sudah disiapkan dan diberikan pakan dengan kandungan protein 18\% dan energi metabolisme $2900 \mathrm{kkal} / \mathrm{kg}$ setelah memasuki periode grower itik dipindahkan ke kandang grower dan diadaptasikan dengan ransum untuk untuk periode grower.

Ransum yang diberikan dengan memanfaatkan tepung biji durian. Pengolahan biji durian menjadi tepung biji durian dilakukan melalui proses seleksi biji, pencucian untuk membuang sisa kotoran yang terdapat pada biji dan selanjutnya dilakukan pengukusan. Pengukusan dilakukan selama 15 menit dengan tujuan untuk menghilangkan HCN yang merupakan pembatas pada penggunaan biji durian karena $\mathrm{HCN}$ dapat mengganggu pertumbuhan itik. Biji durian kukusa selanjutnya diiris dan dikeringkan dengan menggunakan sinar matahari. Kendala saat pengeringan adalah ketergantungan pada sinar matahari sehingga apabila cuaca mendung atau hujan pengolahan biji durian tidak bisa dilakukan mengingat biji durian kualitas baik dihasilkan pada proses kering satu hari. Biji durian kering selanjutnya ditepungkan dan dijadikan bahan penyusun ransum untuk itik talang benih. Hasil pengamatan selama pendampingan menunjukkan ransum yang diberikan pada itik talang benih mempunyai palatabilitas yang baik terlihat dengan tingkat knsumsi ransum yang tinggi dan tercapainya bobot badan dan tercapainya bobot badan rata-rata 1200-1300 gram pada umur 4 bulan. 


\section{KESIMPULAN DAN SARAN}

\section{Kesimpulan}

Kegiatan Iptek Bagi Masyarakat dengan pembinaan pada kelompok Wanita Tani Rumpun Annisa dan Kelompok Wanita Tani Fatimah dalam pengembangan usaha dan pelestarian itik talang benih dapat disimpulkan bahwa kegiatan ini telah memberikan manfaat dalam pengembangan usaha ternak itik. Pemanfaatan biji durian secara optimal sebagai bahan dasar pakan ternak, tidak saja dapat mengurangi pencemaran lingkungan, tetapi juga dapat menekan tingginya harga pakan yang terus berfluktuasi dan terjamin ketersediaannya. Kedua Mitra yang terlibat dalam kegiatan ini paham dan mengerti dalam manajemen penetasan, pemeliharaan itik Talang Benih, teknologi pembuatan tepung biji durian dan manajemen penyusunan ransum itik talang benih dengan bahan dasar tepung biji durian serta mineral organik.

\section{Saran}

Kegiatan Ipteks ini sebaiknya tetap dilakukan oleh kedua kelompok mitra dengan memanfaatkan tepung biji durian yang tersedia cukup banyak sehingga dapat dimanfaatkan sebagai bahan pakan itik talang benih.

\section{DAFTAR PUSTAKA}

BPS, 2013, Laporan Biro Pusat Statistika Provinsi Bengkulu; Produksi Buah-Buahan dan Tanaman Pangan Provinsi Bengkulu Tahun 2010, Bengkulu.

Conn, E.E., 1978, Cyanogenesisi The Produstion Of Hidrogen Cyanida By Plants; In Keeler, R.F., K.R. Van Kamper., L.F. James, Ed. Effect Of Porsonous Plants On Livestock, Academic Press, New York. p.301.

Tansil, V., 1990, Pemanfaatan Tepung Biji Durian sebagai Tepung Pembuatan Roti, Tesis Program Pascasarjana Universitas Gadjah Mada, Yogyakarta.

Wiradisastra, M.D.H., 1993, Pengolahan Bahan Baku Pakan, Buku Ajar Program Pascasarjana UNPAD, Bandung.

Rita, Wismalinda, Sunaryadi, dan L. Malianti, 2013, Pemanfaatan Tepung Biji Durian (Durio Zibethinus Murr) dan Suplementasi Mineral Proteinat Dalam Ransum Terhadap Peforman Ayam Broiler, Program Studi Peternakan Fakultas Pertanian Universitas Muhammadiyah Bengkulu. 